\title{
助産婦における妊産裖婦のケア能力習得状況の 変化および影響要因の検討
}

\section{A Study of the Process of Care Ability Acquirement and Factors Influencing the Process -Especially the Ability of Care of Women in Pregnancy and Childbearing-}

\begin{tabular}{|c|c|c|c|}
\hline 澤 & 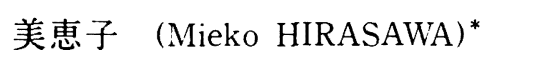 & 新 道 幸 恵 & $(\text { Sachie SINDO) })^{* *}$ \\
\hline 藤 & $(\text { Yoko NAITO })^{* * *}$ & 佐々木 & $(\text { Kazuko SASAKI })^{* * *}$ \\
\hline 吅 & (Minako KUMAZAWA) $^{* * * *}$ & 岡 & $(\text { Megumi MATSUOKA) })^{* * *}$ \\
\hline
\end{tabular}

要 約

助産婦の新卒者が助産婦としての能力に猊熟する過程と, その過程に影響する要因を明らかにする目 的で，国泣および公的助産婦学校 3 校の卒業生 92 名を対象に，妊産婦へのケア能力を中心に，1年閆追 跡調查した。

対象の平均年菊令は23.5歳, 看護婦歷のあるものは34.7\%, その平均職歴は 2.6 年, $200 \sim 999$ 床の病産院 に勤務したものが過半数である。対象者の大半が妊産婦ケア能力の到達状況がよくなるのは就後 1 年時 である。新生児の仮死蘇生術や八イリスク新生児の看護は、1 年時になっても末経験者が多い。

什事ぶリに满足という意識をもつ人の割合は経時的に増加し，それとともに，その意識に相関する好 商謧ケア能力の項目が増加している。職場の人間関係に関する意識にも能力の到達状況と相関が認めら れた。その意識のうち, ケア能力の到達項目の多くと相関がみられたのは, 1 か月時には職場の雲囲気 がよい，6か月時には職員の意見交換が多い，である。

\section{Abstract}

The purpose of this study is to investigate the processes of care ability acquirement-especially the ability of care of women in pregnancy and childbearing-and to find factors influencing these processes. We followed up for one year 92 midwives who graduated recently from three midwifery

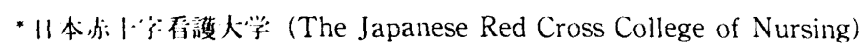

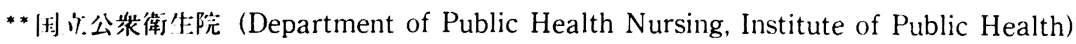

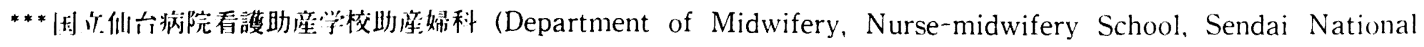
Hospital)

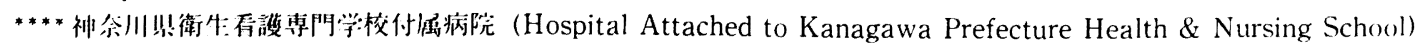

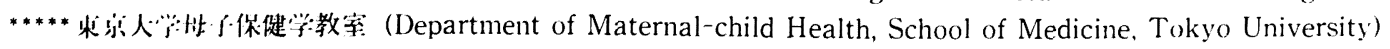


schools respectively, national, public. More than half of the subjects worked at an institute with 200 to 999 beds. The average age of the subjects is 23.5 , and $34.7 \%$ of them have experiences as a nurse, having worked for an average of 2.6 years.

The majority of the subjects attained a good level of care ability after one year. However, many of them have not had experience in resuscitation of a neonate in a state of asphyxia and in the care of a high-risk neonate.

The number of those who find satisfaction in their own way of working increases as time goes on, and at the same time there is an increase in the number of items of care ability in correlation with the satisfaction level. One month after they start working, The achievement level of care ability is in correlation with their impessions that their working places is friendly, and is six months after, is in correlation with their impression that there are good exchanges of opinions among the staff.

\section{I はじめに}

助产婦は産婆の名称で江戸時代から一つの職業 として一般化していたが，教養は低く，明治政府 は，明治元年に太政官布告でその自覚を促した。 さらに明治 7 年に発布された「医制」の中で，喛 婆に関する条項を設けて，産婆の教育の質の向上 を図る方針を明らかにした。このようにして始め られた助産媂教育は，明治32年に制度化された。 この制度は大幅な骨子の変更なく戦前まで続けら れた。終戦後，看護教育全般にわたる改革により， 助産嫦教育も昭和 27 年から新制度の教育に切り替 わった。さらに昭和 43 年の看護基礎教育の教育課 程の改正に伴い, 助産婦の教育課程も昭和 46 年に 改证された。新しい教育は、リプロダクションを コアにして母子保健学を志向したカリキュラムで 棈成さ机て今日に至っている。

娀後の社会情勢は，第 1 次出兴ブームを迎え， 分始の場所が徒来の家庭から徐々に施設内へ移行 していった。一う，助産婦の養成は制度の切り替 えにより，昭和 27 年には養成校 8 校, 定員 185 人と いう状洗であった。施設内助産㛺へのニーズが高

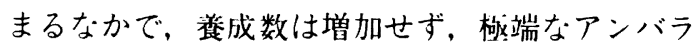
ンスが牛じた。炤和40年には，施設内分婏の割合 が $80 \%$ を超えたが，養成校29校，人兴:考427人で, この作の病院勤務助産婦 1 人当たりの年間出任数 は114.5人であった。このような背景のなかで, 助

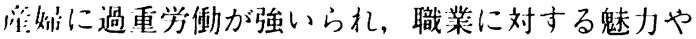
志父の低卜をを米し, 助産婦志願者の低迷状態がし ばらく続いた。その後，年に $2 \sim 3$ 校づつ㖉成校
が新設され，昭和61年には養成校 80 校，入学者 1,500 名に至り, 新卒業生の $80 \%$ は施設に就業して いる1)。

このような社会情勢と助産婦不足から，助産婦 数の充足が優先され，助産婦としての役割や能力 に関する検討が遅れてきた。助産婦の基礎教育の 到達目標に関しての研究は一部あるが, 助産婦の 役割や能力の習得状況を縦断的に追跡調査した研 究は行われていない。また助産婦としての能力の 評定尺度や，役割取得の過程，そ机に影響する要 因や，能力習得の期間についてもあまり明確にさ れていない。助産婦に求められる能力は何か, そ のためには助産婦の基礎教育や卒後教育はどうあ つたらよいか, 助産婦の役割はどのように取得さ れ，質の向上に結び付いていくのか，社会の変化 に伴って要求される能力は何か，そして助産㛿が 夺門職として一般社会人にどのような貢献をすべ きか等の検討が現状から求められている。

そこで今问, 新卒助産婦の役割取得・能力殞得 状海を把握し, 助産婦基礎教育の評価ならびに, 卒後教育のあり方を検討することを目的にして調 查を行った。

\section{II 方 法}

\section{1. 対象と方法}

国让および公的助産婦学校計 3 校の昭和61年 3 月卒業生 92 人中， 86 人を対象に，質問紙調査を卒 業前と卒業後 1 か月・ 6 か月・ 1 年目に行った。 調査の方法は，卒業前は直接配布，卒業後 1 か月， 6 か月，1年は郵送法を用いた。調査の内容は， 
卒業時および卒業後の妊産裖婦のケア能力到達状 況, 職場の人間関係, 勤務内容, 仕事に対する意 識, 仕事上の困難さに対する対処方法, 私的生活 に対する意識, 助産婦になった動機と感想, 性格 (Y G 性格検査を使用), 自我状態 (東大と九大の 心療内科で共同開発されたエゴグラムを使用）で ある。

妊産裖婦のケア能力の到達状況を調べる際の項 目の設定には, 助産婦に要求される認知, 情意, 精神運動領域を含めて, 全人的対応ができる能力 を考虑した。

\section{III 結 果}

回収数は, 卒業前 86 人 $(100 \%), 1$ か月 72 人 $(83.7$ $\%), 6$ か月 71 人 $(82.6 \%) ， 1$ 年65人 $(75.6 \%)$ であり，そ扎らを分析したが、今回はケア能力習 得状海と, 影響要因についての結果を報告する。 ただし，性格上自我状態の関連性については省い た。

\section{1. 対象背景}

平均年㢼は23.5歳, 住居の状況は自宅および寮 の個室が多く，59人 (82.0\%) である。こ机は1 年間ほ上んど変化がない。看護婦歴のない者は 46 人 $(63.9 \%)$ と多い。看護婦歴のある者 25 人 $(34.7$ \%)の平均職歴は2.6年である。勤務している病院 の規模は200床以上999床以下が過半数を占め,

中・大規模病院が多い。

\section{2. 勤務部門・業務内容}

勤務部間は産婦人科病棟, 産科棟, 分娩梀等の 分娩在取り扱う部門に勤務する者が，各調査時点 上も最も多く $86.1 \%$ 在占好てる(表 1 )。専仕妙

\section{表 1 調查時別の勤務部門}

\begin{tabular}{|c|c|c|c|c|c|c|}
\hline \multirow{2}{*}{ 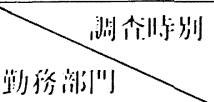 } & \multicolumn{2}{|r|}{1 か川 } & \multicolumn{2}{|c|}{6 か川 } & \multicolumn{2}{|c|}{1 作 } \\
\hline & 数 & $\%$ & 数 & $\%$ & 数 & $\%$ \\
\hline 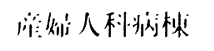 & & (38.9) & & (46.5) & 36 & (55.4) \\
\hline 渞 科 & & (19.4) & & $(22$ & 9 & (13.8) \\
\hline 㚾 & & $(9.7)$ & & $(7.0)$ & & $(7.7)$ \\
\hline 他科上の茈代 & 13 & $(18.1)$ & & (11.3) & & $(4.6)$ \\
\hline$\div \quad 0$ & 10 & (13.9) & & (11.3) & 12 & (18.5) \\
\hline iL' & & 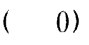 & & ( 1.4$)$ & 0 & 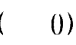 \\
\hline it & 72 & ( 100 ) & $71 \mid$ & $(100)$ & 65 & (100) \\
\hline
\end{tabular}

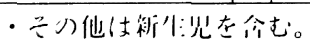

長のいるところで勤務している者 $85.9 \%$ うち, 助産婦の婦長であるのが69\%である。勤務体制は 3 交代制が大部分である。夜勤の回数は卒後 1 か 月を除いては準・深夜勤それぞれに5〜9日が多 く, 卒後 6 か月で一般的な体制になっている。休 日はどの調査時点においても5〜9日が多い。

おもな業務内容として，6 か月以降に $70 \%$ 者 が行っているのは, 産婦の看護, 産婦の入院時の 世話, 新生児の看護, 䙏婦の看護であり, 1 年後 にはこれに分娩介助が加わる。1 年間を通して少 ないのは, 乳幼児の健康診查と個別指導である(図 1 )。

\section{3. 職場の人間関係や仕事に対する意識の変化}

妊産裖婦ケア能力の到達状況の影響要因上し て, 職場の人間関係に対する意識を 6 項目と, 什

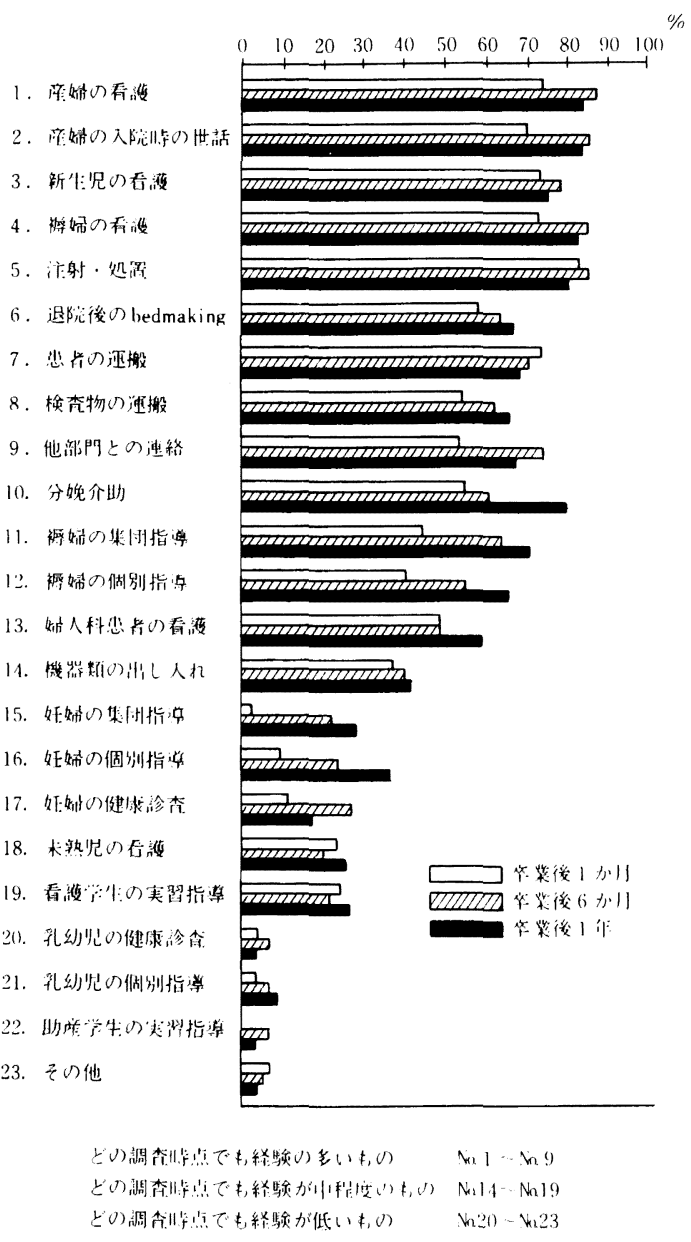

図 1 新卒助産婦のおもな業務内容の経時的变化 
事に対する意識 7 項目を取り上げた。影響要因に 関する項目は，「はい」を 1 とし，「いいえ」を 5 上する 5 段階尺度を用いた。

1 ）職場の人間関係に対する意識の変化

1 年間のどの調査時点においても，普通（3） よりもよい。経時的変化では,「働きやすい雲囲気」 上「医師・看護職との意見交換」を除いて，ス夕 ッフ同士の意見交換, 信頼関係, 仕事の協力, 指 導助言システムは, 卒業後 1 か月の評価が最もよ くなっている(図 2)。

2 ）仕事に対する意識の変化

「存在価値が認められている」,「仕事や職場が自 分に向いている」と思っている者が多く、これら の意識の平均得点は経時的にやや高くなってい る。しかし「仕事ぶりに満足」は経時的に平均得 点は高くなっているが，仕事に対する意識の中で は最も低い。「仕事の失敗が多い」は，経時的に平 均得点が低下している。「先輩にしかられることが 多い」は，経時的な変化はみられないが，「必要な ときに必要な助言を受けている」という意識の平 均得点は年間を通して高い（図 3)。

\section{4. 到達状況}

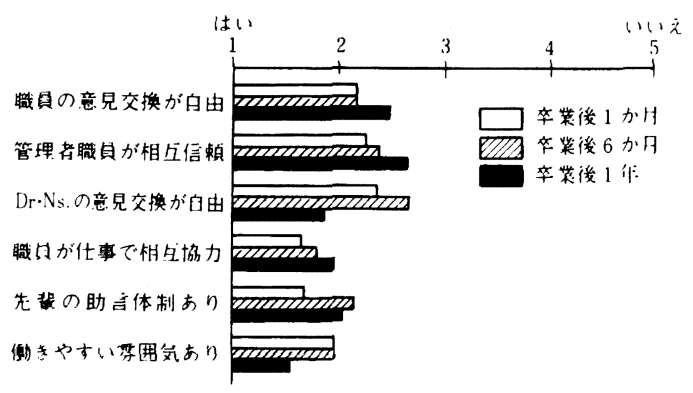

図 2 勤務場所の人間関係に対する意識の変化

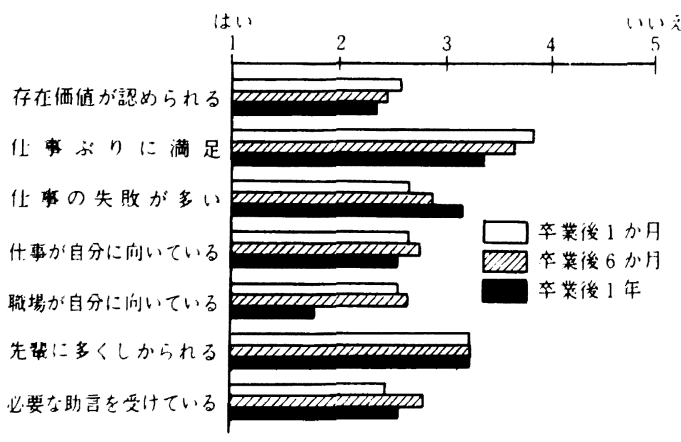

図 3 仕事に対する意識の変化
1 ）調査時期別ケア能力の習得状況

妊産裖婦のケア能力に関する26項目の到達目標 に対して，自己評価により習得状況を点数化した (「できる」1点，「だいたいできる」2点「でき ない」 3 点)。点数が 1 点に近いほど自己評価がよ いことを示す。

卒業時においては, 自己評価得点の平均値が 1.9 未満の習得状況のよいのは表 2 に示すように，妊 婦 1, 産婦 1, 裖婦 1, 一般的ケア 4 の計 7 項目 である。2.3以上の習得状況の悪いのは, 産婦 3 , 新生児 1 の 4 項目である。

卒業後 1 か月では, 習得状況のよいのは, 6 項 目で，悪いのは10項目になってる。

卒業後 6 か月では, 習得状況のよいのは 9 項目, 覀いのは1項目のみである。

卒業後 1 年で, 習得状況のよいのは19項目, 悪 いのはなくなっている。

妊産袮婦のケア能力の経時的変化は, 卒業後 1 か月で卒業時よりいったん悪くなるが，6か月以 降は順次よくなっている。一般的ケア能力は卒業 時より卒業後 1 か月のほうがよく，卒業後 1 年で 最もよい。卒業後 1 年で比較的悪いのは, 助産計 画の立案, 新生児仮死蘇生である（表 2$) 。$

\section{5. 到達状況に影響する要因}

ケア能力の到達状況に影響する要因として, 勤 務場所, 業務内容, 仕事に対する意識, 勤務場所 の人間関係をあげて検討した。到達状況と影響要 因は相関係数を求め $\mathrm{t}$ 検定を行った。

1) 勤務場所々到達状況

1 年目において自己評価得点が 1 点であるもの が70\%以上に達している業務内容と勤務場所をみ ると, 一般的ケアの与薬, 検査, 浣腸と, 裖婦の 健康診断の 4 項目である。その 4 項目とも混合病 棟勤務者であり，浣腸は分婏室勤務者も同様であ った。60\%以上の者が 1 に到達できているのは, 産痛緩和指導と胎児の健康状態の判断の 2 項目 で,この項目も混合病棟勤務者が多かった。1 の到達者が $20 \%$ 以下であったケア能力は, 妊娠経 過の診断, 好婦の心理社会的援助，妊婦や家族へ の準備教育, 産婦の心理に応じた指導, 産後の性 生活指導, 八イリスク新生児の援助, 新生児仮死 蘇生があげられる。そのうち，好娠の経過診断な ど最初にあげた 4 項目は, 分娩室勤務者である。 


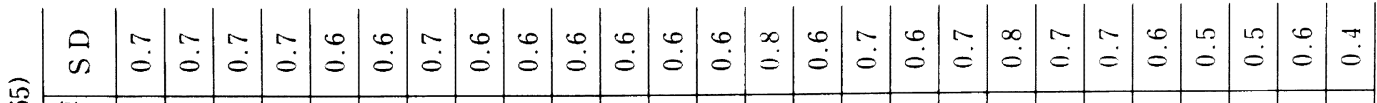

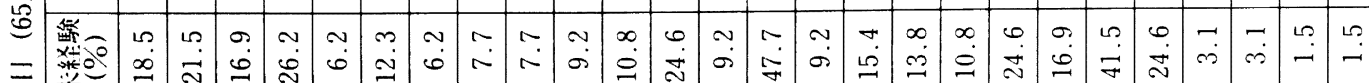

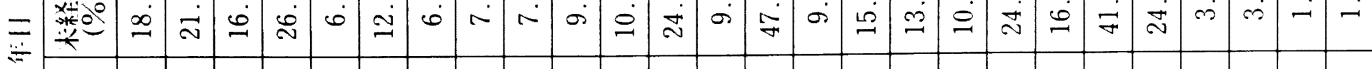

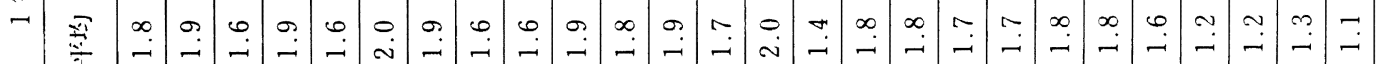

๑ ᄀ

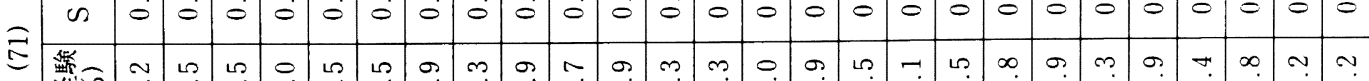

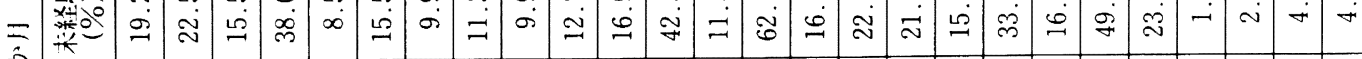

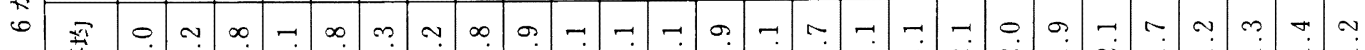

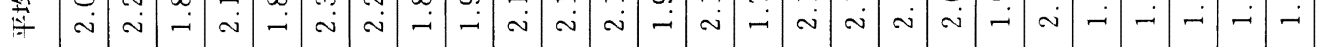

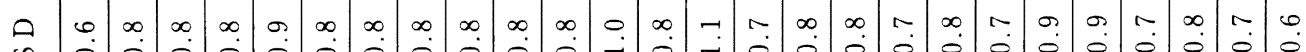
㣽

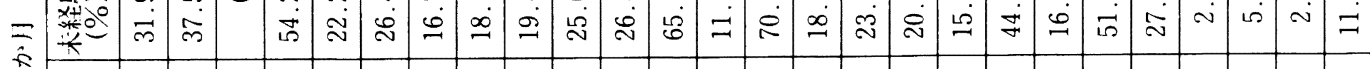

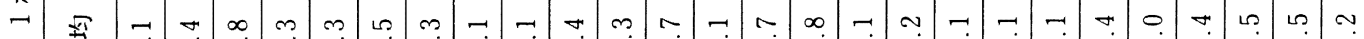

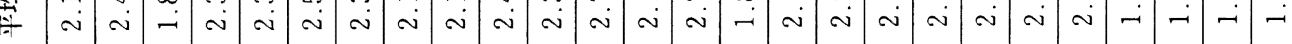

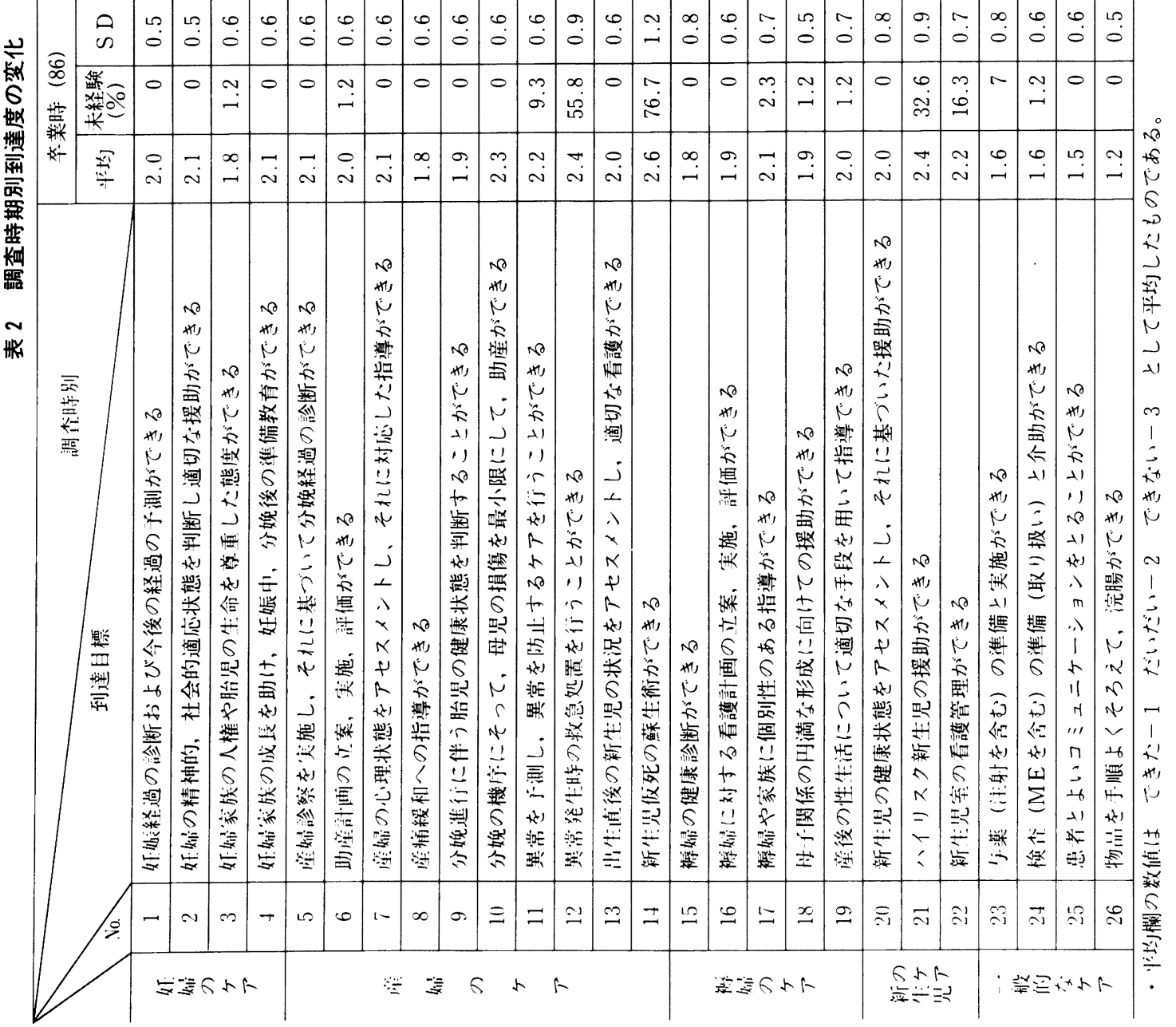




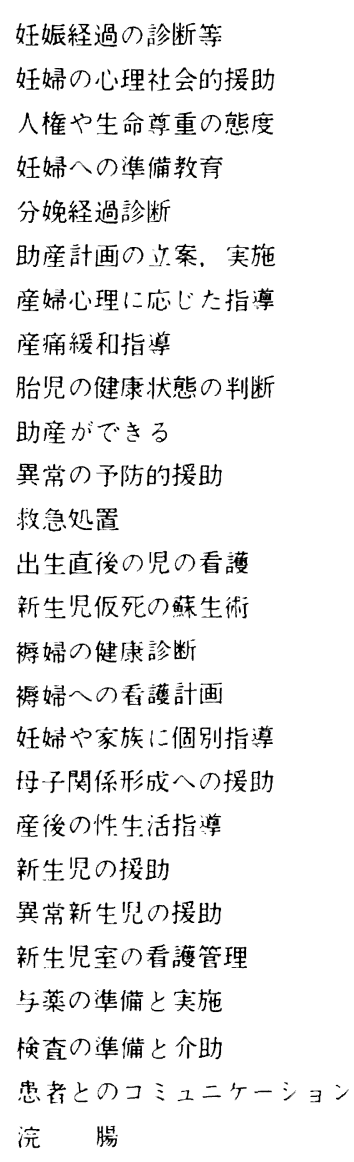

妊娠経過の診断等

妊婦の心理社会的援助

人権や生命尊重の態度

分婏経過診断

助産計画の方案，実施

地指

胎児の健康状態の判断

的がき

救急処置

出生直後の児の看護

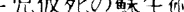

褯婦への看護計画

妊媂や家族に個別指導

産後の性生活指章

新生児の援助

異常新生览の擐助

新生児室の看護管理

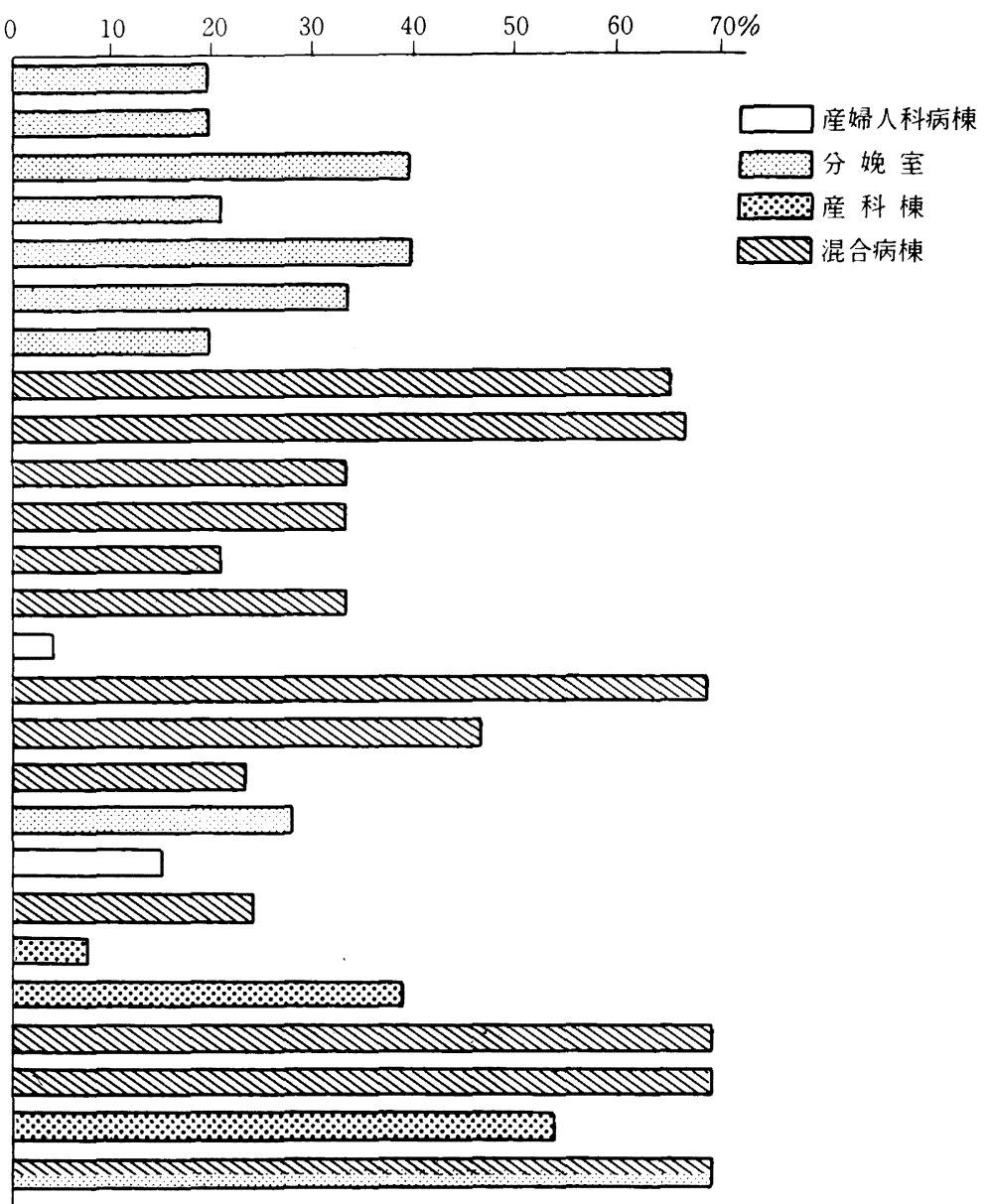

*到達者の制合が最も多い勤務部門のみ

\section{図4 勤務部門別到達状況(卒業後 1 年の到達)}

举後の性生活指導と新生児仮死蘇生は産婦人科勤 狢者で，八イリスク新生児の援助は産科勤務者で ある（図 4 ）。

木経験考の多い業務内容と勤務部門をみると， $30 \%$ 以にの考が末経騒の項目は，26項目中20項目 ある。なかでも産後の性生活指導と妊婦の社会心 理的援助，好婦や家族への準備教育は末経験者が 多い。勤務場所では，新生児室勤務者が15項目， 分娭室勤務考が 8 項目末経験であった（図 5 )。

2 ）仕事に対する意識と到達状況

1 か月では妊媆や家族への準備教育，新生児仮 死蘇生ができた時に，自己の你在価值を認め，仕 事ぶりに满足し，職場が自分に向くと感してている が，6 か月以降には相関はみられない（ $\mathrm{R}=0.03$ 以.)。
仕事ぶリの満足の意識は, 1 年目で産婦 3 , 褲 婦 1 , 新生児 2 の 6 項目と相関があった。こ机ら は助産婦として自立して行っていかなけ机ばなら ない内容で，この項目が実践できたときに満足感 をもっている。分娭経過の診断, 出生直後の新生 児のケア，八イリスク新生児のケアの到達は，仕 事が自分に向く，職場が自分に向く，仕事ぶりに 満足するの三つの意識と相関があった（表 3）。

3 ）人間関係に関する意識と到達状況

年間を通して，人間関係と相関のみられた項目 は, 妊娽や家族への準備教育, 助産計画, 分婏経 過の診断，新生児仮死蘇生であり，与薬は負の相 関であった。

管理者との相互信頼, 先辈の助言システムのあ るという意識は， 1 年目に助产計画，新生児仮死 


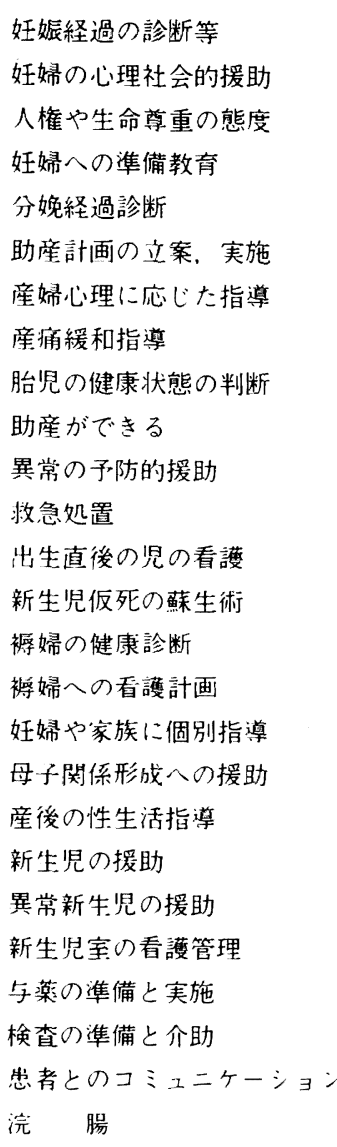

妊娠経過の診断等

妊婦の心理社会的援助

人権や生命尊重の態度

妊媂への準備教育

分婏経過診断

助産計画の立案、実施

産痛緩和指導

胎児の健康状態の判断

助産ができる

異常の予防的援助

校急処晴

出生直㳇の児の看譄

袮婦の健康診断

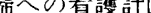

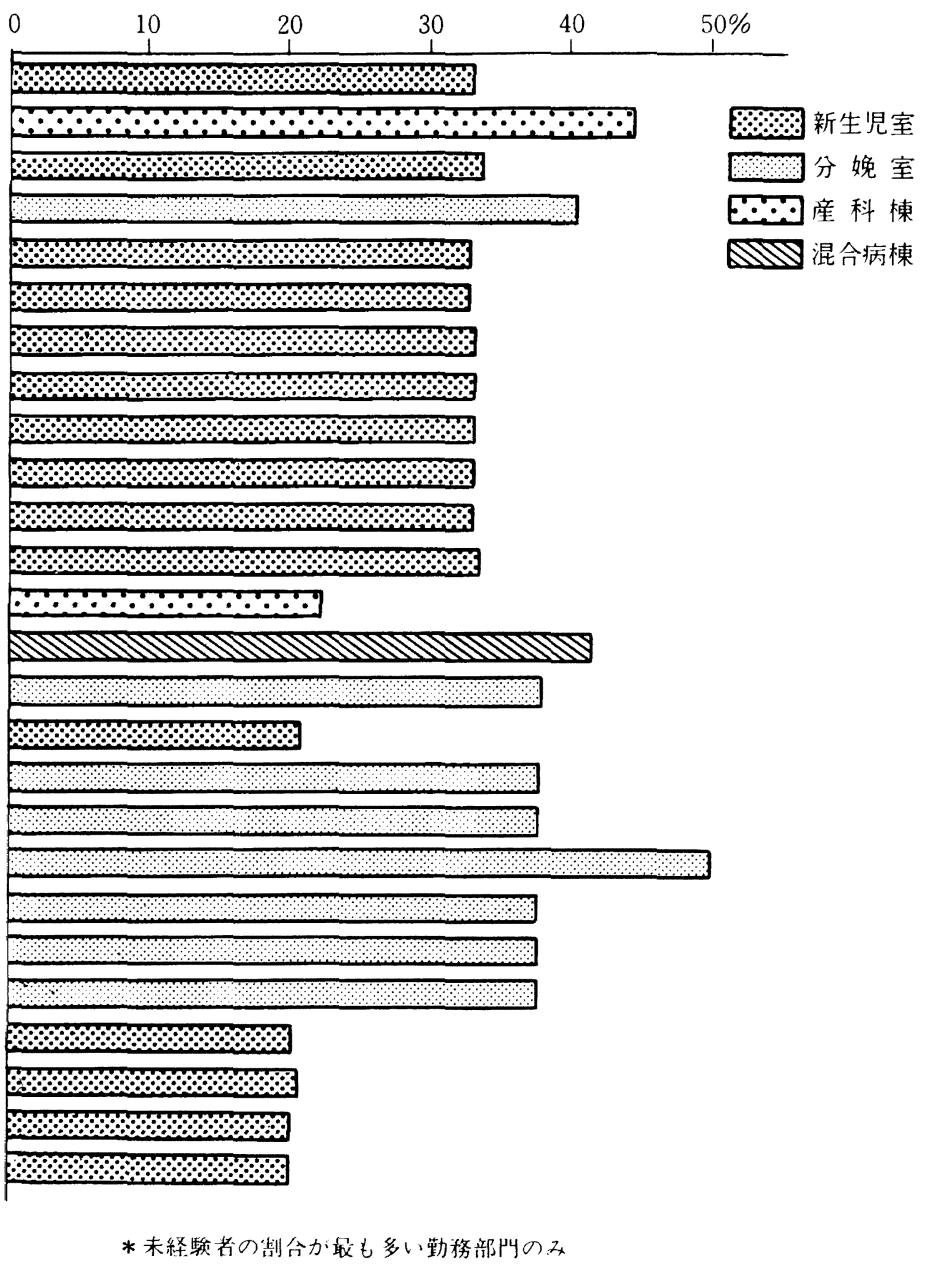

図 5 勤務部門別到達状況(卒業後 1 年の到達)
蘇氘の白し严価得点の平均值が高い。「働きやすい 管明剱上いう意識と, 分娩経過の診断, 救急処 疽の到達上相関がみら机た（表 4 ）。

\section{6. 仕事に対する意識と職場の人間関係との関連} 性

「職場が自分に向いている」という意識は，「職場 に扮ける你在価值」，「仕事ぶッにに満足」，「仕事が 门分に向いている」「必要時の指導を受けている」 の意識との相関がみられる。さらに，「職場が自分 に问いている」という意識は，「管理者との相互倍 頼」を除くすべての人間関係と相関があり，特に 「スタッフ闹士:の意見交換」，「働きやすい霑囲気」 のある人問関係の職場との相関が高い。

「スタッフ[i门]士の意見交換」のある職場は，「必要 時の指䆃在受けている」，「仕事が自分に向いてい
る」,「職場が自分に向いている」の意識との相関 もみられた（表 5 )。

\section{IV 考 察}

新卒助産钕のケア能力の到達状沈について, 伸 びる領域, 伸びにくい領域, 到達度のよい項目, 覀い項目，末経騃の多い項目を勤務場所や，経騃 の度合いと関連づけて検討した。さらにケア能力 習得の関連要因として，勤猛場所，仕事に対する 意識, 職場の人閒関係と到達度の結果より，今後

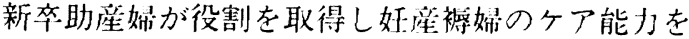
高めていくにはどのようなケアが必要かを考察す る。

\section{1. 妊産裖婦ヶアの到達度と関連要因の検討}

1) 好滻褯婦ケアの領域ごとの到達度 
表 3 新卒助産婦の仕事に対する意識と到達度との相関関係

\begin{tabular}{|c|c|c|c|c|c|c|c|c|c|c|c|c|c|c|c|c|c|c|c|}
\hline \multirow{2}{*}{\multicolumn{2}{|c|}{ 11 $11:=$}} & \multicolumn{3}{|c|}{ 存在価值 } & \multicolumn{3}{|c|}{$\begin{array}{l}\text { 仕事ぶりに } \\
\text { 満足 }\end{array}$} & \multicolumn{3}{|c|}{$\begin{array}{l}\text { 仕事上の } \\
\text { 失敗 }\end{array}$} & \multicolumn{3}{|c|}{$\begin{array}{l}\text { 仕事が } \\
\text { 自分に向く }\end{array}$} & \multicolumn{3}{|c|}{$\begin{array}{l}\text { 職場が } \\
\text { 自分に向く }\end{array}$} & \multicolumn{3}{|c|}{$\begin{array}{l}\text { 上司に } \\
\text { しかられる }\end{array}$} \\
\hline & & 1 & 6 & 12 & 1 & 6 & 12 & 1 & 6 & 12 & 1 & 6 & 12 & 1 & 6 & 12 & 1 & 6 & 12 \\
\hline \multirow{3}{*}{ 奴: } & 1 & & & & & 0 & & & & & & 0 & & & & & & & \\
\hline & 2 & & & & & & & & & & & & & 0 & & & & & \\
\hline & 3 & & & & & & & & & & & & & & & & & & \\
\hline 姅 & 4 & 0 & & & 0 & & & & & & & & & 0 & & & & & \\
\hline \multirow{6}{*}{ 常 } & 5 & & & & & & 0 & $\Delta$ & & & & & & & & 0 & & & \\
\hline & 6 & & & & . & & 0 & & & & & & & & & & & & \\
\hline & 7 & & & & 0 & & 0 & & & & & & & & & & & & \\
\hline & 8 & & & & & & & & & & & & & & & & & & \\
\hline & 9 & & & & & & & & & & & & & & & & & & \\
\hline & 10 & & & & & & & & & & & & & & & & & & \\
\hline \multirow{4}{*}{ Lifi $^{1}$} & 11 & & 0 & & & 0 & & & & & & & & & & & & & \\
\hline & 12 & & & & & & & & & & & & & & & & & & \\
\hline & 13 & & & & & 0 & & & & & & & 0 & & & 0 & & & \\
\hline & 14 & 0 & & $\triangle$ & 0 & & & & & & & & & 0 & & & & & \\
\hline \multirow{3}{*}{ 被 } & 15 & & & & & & 0 & & & & & & & & & & & & \\
\hline & 16 & & 0 & & & & & & & & & & & & & & & & \\
\hline & 17 & & & & & & & & & & & & & & & & & & \\
\hline \multirow[t]{2}{*}{ 住i } & 18 & & & & & & & & & & & & & & & & & & \\
\hline & 19 & & & & & & & & & & & & & & & & & & \\
\hline \multirow{3}{*}{$\begin{array}{l}\text { 新 } \\
\text { 坚 } \\
\text { 北 }\end{array}$} & 20 & & & & & 0 & & & & & & 0 & & & & & & & \\
\hline & 21 & & & & & & 0 & & & & & 0 & & & & 0 & & $\triangle$ & \\
\hline & 22 & & & & & & 0 & & & & & & & & & & & & \\
\hline \multirow{4}{*}{$\begin{array}{l}\text { 悲 } \\
\text { 㗏 }\end{array}$} & 23 & & & & & & & & $\triangle$ & & & 0 & & & & & & & \\
\hline & 24 & & & & & & & & & & & & & & & & & $\triangle$ & \\
\hline & 25 & & & & & & & & & & & & & & & & & & \\
\hline & 26 & & & & & & & & & & & & & & & & & & \\
\hline
\end{tabular}

表 4 新卒助産婦の職場の人間関係に関する意識と到達状況との相関関係（時期別）

\begin{tabular}{|c|c|c|c|c|c|}
\hline & スタッフ闬 1:の意見交換 & 管理者との相不倍頼 & スタッフ間の協力 & 先輩の助言システム & 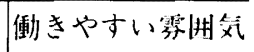 \\
\hline 1 か川 & & 新生巟仮死蘇生 & & & 新生児仮死蘇生 \\
\hline 6 か川 & 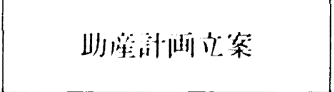 & & $\begin{array}{l}\text { 妊嫦・家族への } \\
\text { 準備教育 }\end{array}$ & & \\
\hline 12か川 & & $\begin{array}{l}\text { 助座計画立案 } \\
\text { 新生児仮死蘇生 }\end{array}$ & & $\begin{array}{l}\text { 新生児做死蘇生 } \\
\triangle \text { 与澘 }\end{array}$ & $\begin{array}{l}\text { 分婏経過の診断 } \\
\text { 救急処置 }\end{array}$ \\
\hline
\end{tabular}

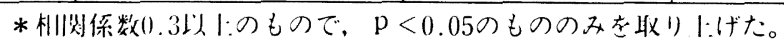

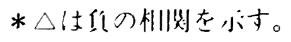

新卒助産婦のケア到達状況を, 卒業時と卒業後 1 年時の各領域の到達度の平均值を出して比較し てみる上，卒業時には，一般的看護，裖婦のケア， 姄姹のケア, 产婦のケア, 新牛児のケアの順の到
達度であった。卒業後 1 年目には，一般的看護， 褯婦のケア, 新生児のケア, 産婦のケア, 弤婦の ケアの到達順であった。

一般的看護と袮婦のケアの領域は, 卒業時より 
表 5 新卒助産婦の仕事に対する意識と職場における人間関係の相関関係

\begin{tabular}{|c|c|c|c|c|c|c|c|c|c|c|c|c|c|c|}
\hline & & \multicolumn{7}{|c|}{ 仕事に対する意識 } & \multicolumn{3}{|c|}{ 人間 } & \multicolumn{3}{|c|}{ 関係 } \\
\hline & & $\begin{array}{l}\text { 職 } \\
\text { 場 } \\
\text { に } \\
\text { 占 } \\
\text { け } \\
\text { る } \\
\text { 存 } \\
\text { 在 } \\
\text { 価 } \\
\text { 値 }\end{array}$ & $\begin{array}{l}\text { 仕 } \\
\text { 事 } \\
\text { 䛠 } \\
\text { ! } \\
\text { に } \\
\text { 満 } \\
\text { 足 }\end{array}$ & $\begin{array}{l}\text { 仕 } \\
\text { 事 } \\
\text { 上 } \\
\text { の } \\
\text { 失 } \\
\text { 敗 }\end{array}$ & $\begin{array}{l}\text { 仕 } \\
\text { 事 } \\
\text { が } \\
\text { 自 } \\
\text { 分 } \\
\text { に } \\
\text { 向 } \\
\text { い } \\
\text { て } \\
\text { る }\end{array}$ & $\begin{array}{l}\text { 職 } \\
\text { 場 } \\
\text { が } \\
\text { 自 } \\
\text { 分 } \\
\text { に } \\
\text { 向 } \\
\omega \\
\text { て } \\
\text { る } \\
\text { る }\end{array}$ & $\begin{array}{l}\text { 上 } \\
\text { 司 } \\
\text { に } \\
\text { し } \\
\text { か } \\
ら \\
れ \\
\text { る }\end{array}$ & $\begin{array}{l}\text { 必 } \\
\text { 要 } \\
\text { 時 } \\
\text { の } \\
\text { 指 } \\
\text { 導 }\end{array}$ & $\begin{array}{l}\text { ス } \\
\text { 夕 } \\
\cdots \\
\text { ㄱ } \\
\text { 同 } \\
\pm \\
\text { の } \\
\text { 意 } \\
\text { 兒 } \\
\text { 交 }\end{array}$ & $\begin{array}{l}\text { 管 } \\
\text { 理 } \\
\text { 者 } \\
\text { と } \\
\text { の } \\
\text { 相 } \\
\text { 名 } \\
\text { 信 } \\
\text { 頼 }\end{array}$ & $\begin{array}{l}\text { 医 } \\
\text { 師 } \\
\text { と } \\
\text { の } \\
\text { 意 } \\
\text { 兒 } \\
\text { 效 }\end{array}$ & $\begin{array}{l}\text { ス } \\
\text { 夕 } \\
\text { " } \\
7 \\
\text { 間 } \\
\text { の } \\
\text { 協 } \\
\text { 力 }\end{array}$ & $\begin{array}{l}\text { 先 } \\
\text { 輩 } \\
\text { } \\
\text { 助 } \\
\text { 言 } \\
\text { シ } \\
\text { 文 } \\
\text { テ } \\
\text { 厶 }\end{array}$ & $\begin{array}{l}\text { 働 } \\
\text { き } \\
\text { や } \\
\text { す } \\
\cdots \\
\text { 霝 } \\
\text { 曲 } \\
\text { 気 }\end{array}$ \\
\hline \multirow{7}{*}{$\begin{array}{l}\text { 化 } \\
\text { 止 } \\
\text { に } \\
\text { 刘 } \\
\text { 寸 } \\
\text { る } \\
\text { 意 } \\
\text { 識 }\end{array}$} & 職場に扮ける存在価值 & & & & $\bigcirc$ & 0 & & & & & & & & \\
\hline & 仕事ぶリに満足 & & & $\triangle$ & & O & & & & $\bigcirc$ & & & & \\
\hline & 訨求上の失敗 & & $\triangle$ & & & & & & & & & & & \\
\hline & 訨事が自分に向いている & $\bigcirc$ & & & & 0 & & & 0 & & & & & \\
\hline & 職場が自分に向いている & 0 & 0 & & $\bigcirc$ & & & O & O & & O & O & $\bigcirc$ & \\
\hline & 上、间にしかられる & & & & & & & & & & & & & \\
\hline & 必要時の指導 & & & & & 0 & & & 0 & 0 & $\bigcirc$ & 0 & & $\bigcirc$ \\
\hline \multirow[b]{2}{*}{ 人 } & スタッフ同士の意見交換 & & & & 0 & 0 & & O & & O & 0 & 0 & O & 0 \\
\hline & 管理者上の相互信頼 & & 0 & & & & & O & $\bigcirc$ & & 0 & & 0 & \\
\hline 湔 & 医師上の意見交換 & & & & & 0 & & O & $\bigcirc$ & $\bigcirc$ & & & & 0 \\
\hline 阅 & スタッフ間の協力 & & & & & $\bigcirc$ & & 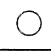 & O & & & & 0 & \\
\hline \multirow[t]{2}{*}{ 係 } & 先輩の助言システム & & & & & 0 & & & 0 & O & & $\bigcirc$ & & \\
\hline & 働きやすい雲囲気 & 0 & & & & 0 & & $\bigcirc$ & $\bigcirc$ & & 0 & & & \\
\hline
\end{tabular}

* $\mathrm{p}<0.05$ もののみを取り上げた。

相威係数 $\bigcirc 0.3$ 以上 0.5 末満 $\triangle-0.5$ 末満

0.5 以上. $\Delta-0.5$ 以上

到達度がよかったが，この領域は，それぞれ65\% 以上の者が業務経験をしているので, 経験に比例 して一般的看護と袮婦のケア能力は伸びていると もいえる。新生児のケアは，卒業時には到達度の 低い領域であったが，新生児看護の経験を70\%以 上の者が行い，経験に伴い平均的に新生児のケア 能力は伸びている。能力の伸びの悪いのは，妊婦 ケアの領域で，卒業後は妊婦の健康診査を除いて 経時的に伸びているが，ヶア経験は $40 \%$ 以下であ る。産婦ケアの領域も $80 \%$ 以上の者が経験し, 経 験に比例し能力を習得しているといえる。総体的 には，各領域とも経験に比例して到達度は伸びて いるといえよう。

2 ）未経験項目と到達度との関連

新卒者は救急処置, 新生児仮死蘇生，八イリス ク新生児の援助を除いて，卒業時までにはほぼ経
験して卒業している。卒業後は，勤務場所や勤務 交代の有無により未経験項目が生じている。40\% 以上の者の未経験項目は，新生児仮死蘇生，八イ リスク新生児の援助の 2 項目である。20\%以上の 者では，妊婦の心理社会的置助，妊婦や家族への 準備教育, 救急処置, 産後の性生活指導, 新生児 室の管理の 5 項目である。これら未経験 7 項目中, 新生児仮死蘇生, 妊婦の心理社会的援助, 妊婦や 家族への準備教育，救急処置の 4 項目は，未経験 者の多い項目で到達度は覀い。この未経験の多い 項目は，より高度な判断と的確なケアが要求され 訓練を要する項目ともいえる。しかし，産後の性 生活指導，八イリスク新生児の援助，新生児室の 管理は未経験者は多いが，経験している者は経時 的に確実に到達度は伸びている。したがって，複 雑な要素を含み的確な判断とケアを要求される項 
目も，経験する機会を与え支掼することにより， 到達度は伸びる可能性があるといえる。

3 ）ケア項目ごとの到達度との関連

各ケア項目ごとの到達度でみると，到達度がよ りよいのは, 一般的ヶアを除いて, 生命を尊重し た態度, 分婏経過の診断, 産痛緩和, 胎児の健康 診断, 出生直後の新生児のケア, 裖婦の健康診断, 母子関係形成への援助, 産後の性生活指導, 新生 児室の管理の 9 項目である。

能力が経時的に伸びているのは, 分婏経過の診 断, 胎児健康状態の判断, 出生直後新生児のケア, 裖婦の健康診断, 産後の性生活指導である。能力 の到達度は高くないが経時的に伸びてきているの は, 助産, 異常の予測と予防, 救急処置, 新生児 仮死蘇生，ハイリスク新生児の援助である。

能力の伸びの悪いのは, 妊娠経過の診断, 妊婦 の心理社会的援助，妊婦や家族への準備教育，助 産計画, 産婦心理アセスメント, 褯婦看護計画, 新生児健康状態アセスメントである。

能力の到達度は高くなくても，経時的に伸びて いる項目中, 救急処置, 新生児仮死蘇生, 八イリ スク新生児の援助は末経験者の多い項目だが, 経 験者の伸び率はよく，適切な指導のもとにケア体 験を重ねていると推測される。

能力の伸びの悪い項目は, 妊婦のケア領域であ る。この領域は未経験者の多い領域であるが, 産 婦ケア領域では救急処置と新生児仮死蘇生を除い て, 経験の多い項目である。そのなかで助産計画 上産婦心理アセスメント，裖婦看護計画，新生児 健康状態のアセスメントの伸びの悪いことは, 全 人的に対象を理解し，的確な情報よりアセスメン トをしてケア計画を立案する能力の習得が悪いと いうことがいえる。

\section{4 ）到達度と勤務場所の関連}

到達者つまり「できた」と回答した者の割合の 多かったのは, 図 4 に示すように混合病棟であり, 少なかったのは分婏室勤務であった。未経験者の 多いのは図 5 のとおり新生児室，分婏室であった ことから，各ケア能力が習得されるまでは，未経 験項目がなく，幅広い対応ができるようなケア経 験をさせる体制づくりが必要であろう。

5 ) 仕事に対する意識と職場の人間関係との関 連
1 年目で仕事ぶりに満足するという意識と相関 のみられたケア能力 6 項目中, 分婏経過の診断, 裖婦の健康診断, 新生児室の管理の到達度はよく, ハイリスク新生児の援助も経時的に能力は伸びて いるが, 助産計画と, 産婦心理アセスメント能力 の伸びは悪い。したがってこれらのケア項目に対 しては，能力習得に向けてよりいっそう職場にお ける指導助言システムの強化が必要である。

職場の人間関係では, 管理者と相互信頼がもて, 先輩の助言システムのあるところでは, 助産計画 と新生児仮死蘇生の到達がよい。新生児仮死蘇生 は, より高度なケアで, 習得には経験问数が必要 と思われるが, 経験者の能力の伸びのよいことか ら, 職場の信頼関係や助言システムは重要な能力 習得要因と思われる。同様に働きやすい雲囲気の 職場は, 分婏経過の診断と救急処置の到達がよい。 この項目も分婏中，時々刻々と変化する母児の状 況に，的確な判断と敏速でかつ適切なケア能力が 要求される項目なので, 職場の中で必要なときに 必要な指導を受けられる雲囲気が必要である。

\section{2. 助産婦の能力を伸ばすための卒業後のケア}

助産婦の基礎教育においては, ケア項目中, 救 急処置, 新生児仮死蘇生, 八イリスク新生児の援 助を除いた23項目は一通り実習体験をして卒業し ている。末経験の多い救急処置, 新生児仮死蘇生, 八イリスク新生児の援助は, 到達度が悪いが一刻 を争う救命と、より高度な判断に基づいたケアを 要する内容なので, 万遍なく経験させることは不 可能である。この項目以外に到達度が悪いのは, 妊産婦や家族に対する心理社会的援助である。し たがって基礎教育では，心理社会的援助の能力習 得をするのに必要な家族心理に関する理論や，母 子や家族を対象にしての危機理論・ストレス理 論・役割取得の理論を十分に教育する必要がある。 3 項目以外の他の項目は, 基礎教育の中で充実さ せ, 卒業後習熟していける素地づくりが必要であ ろう。

卒業後 1 年の到達度による習得状況では, ケア 領域，勤務場所による差がみられた。伸びの悪い 項目はおもに経験の少ない項目であるが，気にな るのは対象理解に基づいて，アセスメントをし， ケア計画を立案する能力が伸びていないことであ る。助産婦は対象を全人的に理解しての対応であ 
る。それには心理社会的側面の理解や, きめ細か な助産計画を立案して総体的に援助する能力が要 求される。基礎教育で経験の少なかった，高度な 判断上的確なケアが要求される救急処置等は, 卒 業後も経験は少ないが, ケア経験者の習得状況は よい。総合的に判断する能力や，的確なケアを必 要上する項目は, 仕事に対する意識や職場環境に 関連がみられた。このことから卒業後の継続教育 のあり方について，次のことが示唆される。

(1)高度な判断とケアを要する内容は, 基礎教育 ではその素地を築くのが不十分であることから， 卒業後, 適切な指導のもとでケア体験をさせて能 力を高めることが必要である。

(2)妊産裖婦のケア能力習得のためには卒業後ケ ア経験をさせる必要があると思われる。そのため には，個々の経験や習得状況を考虑して，末経験 項目や習得状況に偏りが生じないように，適宜勤 務交代などを行い，必要なケア体験ができるよう な配慮が必要であろう。

(3)妊産裖婦や家族に対する心理社会的援助は, 能力習得上伸び悩んでいる内容なので, 卒業後も 一貫して系統だてた教育が必要と思われる。

(4)能力習得と職場環境は関連性があるので, 働 きやすい職場が要求される。すなわち，お互いを 尊重し,関係職種と自由に意見交換ができること。 職場では常に問題意識をもち, 課題を明確にして 相互に刺激しあえること。新卒業生には適切な示 唆や助言を必要時に与えられる体制づくりを追求 していかなければならない。

これからの助産婦の資質を向上させるには，妊
産裖婦への援助は必須ではあるが，これだけの能 力に片寄らせないこと，すなわち母性の各ライフ ステージに対応する能力や, 時代に適応し, 对象 者のニーズに即した幅広い母子の保健指導能力 や，一貫した母子のプライマリーケア能力の向上 のための方略を開発していく努力が必要であろう と考えられる。

したがって, 妊産裖婦のケア能力以外の能力習 得状況についての追跡調査をしていくことが, 今 後の研究課題であると思われる。

\section{引用文献}

1。全国助産婦教育協誐会・業務検討委員会：助産婂の採 用状況に関する調查報告書，1988。

\section{参考文献}

1. Abraham H. Maslow: Toward a Psychology of Being, 1962, 上田吉一訳, 完全なる人間, 誠信書房, 1985。

2. Carl Rogers: Carl Rogers on Personal Power,1977. 畠瀬稔他訳, 人間の潜在能力, 創元社, 1985。

3. 川出富貴子他：卒業時における看護技術到達目標に対 する期待と要望, 看護展望, 7 ( 3 )，11-25,1982。

4. 加藤奈智子他：助産婦学生の入学洔における看護技術 の定着度に関する一調査：ナースステーション, 8 ( 2 ), 48-53, 1978。

5. Meleis, A, I: Role Insufficiency and Role Supplementation, A Conceptual Framework. Nursing Research, $24: 4,1975$ 。

6. 渡辺秀樹：個人·役割・社会，思想, 686,98-121, 1981。

7. 全国国立大学医学部付属助産婦学校教務主:任連絡協議 会：助産婦学生実習指針, 看護教育, $18(9), 579$ 586,1977 。

8. 全国助産婦教育協議会教育制度委員会・小委員会：助 産婦教育到達目標，看愎教育，27(13)，791-820,1986。 